\title{
Lanthanide chloride complexes of amine-bis(phenolate) ligands and their reactivity in the ring-opening polymerization of $\varepsilon$-caprolactone $\dagger$
}

\author{
Charlotte E. Willans, ${ }^{a}$ Mikhail A. Sinenkov, ${ }^{b}$ Georgy K. Fukin, ${ }^{b}$ Kristina Sheridan, ${ }^{c}$ Jason M. Lynam, ${ }^{a}$ \\ Alexander A. Trifonov*b and Francesca M. Kerton $* c$
}

Received 8th February 2008, Accepted 16th April 2008

First published as an Advance Article on the web 20th May 2008

DOI: 10.1039/b802219d

Reaction of two equivalents of $n$-BuLi with sterically demanding amine-bis(phenol) compounds, $\mathrm{H}_{2} \mathrm{O}_{2} \mathrm{NN}^{\prime R}\left(\mathrm{Me}_{2} \mathrm{NCH}_{2} \mathrm{CH}_{2} \mathrm{~N}\left\{\mathrm{CH}_{2}-3,5-\mathrm{R}_{2}-\mathrm{C}_{6} \mathrm{H}_{2} \mathrm{OH}\right\}_{2} ; \mathrm{R}=t\right.$ - $\mathrm{Bu}$ or $t$-Pe (tert-pentyl)) yields isolable lithium complexes, $\mathrm{Li}_{2}\left(\mathrm{O}_{2} \mathrm{NN}^{\prime \mathrm{R}}\right)$, in good yields. Upon reaction with one equivalent of $\mathrm{LnCl}_{3}(\mathrm{THF})_{x}$, the lithium salts afford rare earth amine-phenolate chloride complexes in good yields, $\mathrm{Ln}\left(\mathrm{O}_{2} \mathrm{NN}^{\prime \mathrm{R}}\right) \mathrm{Cl}(\mathrm{THF}) ; \mathrm{Ln}=\mathrm{Y}, \mathrm{Yb}, \mathrm{Ho}, \mathrm{Gd}, \mathrm{Sm}$, Pr. Crystals of $\mathrm{Y}\left(\mathrm{O}_{2} \mathrm{NN}^{t-\mathrm{Bu}}\right) \mathrm{Cl}(\mathrm{THF}), \mathbf{1}$, and $\mathrm{Sm}\left(\mathrm{O}_{2} \mathrm{NN}^{\prime \prime-\mathrm{Bu}}\right) \mathrm{Cl}(\mathrm{DME}), \mathbf{2}$, suitable for single crystal X-ray crystallographic analysis were obtained. In contrast to previously reported $\left[\left\{\mathrm{Gd}\left(\mathrm{O}_{2} \mathrm{NN}^{\prime t-\mathrm{Pe}}\right)(\mathrm{THF})(\mu-\mathrm{Cl})\right\}_{2}\right]$ and related $\mathrm{La}$ and Sm complexes, these species are monomeric. 1 contains $\mathrm{Y}$ in a distorted octahedral environment bonded to two amine, two phenolate, one THF and one chloride donor. 2 contains $\mathrm{Sm}$ in a distorted capped trigonal prismatic environment bonded to two amine, two phenolate, two DME oxygens and one chloride donor. The $\mathrm{Ln}\left(\mathrm{O}_{2} \mathrm{NN}^{\prime \prime-\mathrm{Pe}}\right) \mathrm{Cl}(\mathrm{THF})$ complexes were active initators for the controlled ring-opening polymerization of $\varepsilon$-caprolactone with a tendency to form low molecular weight cyclic polyesters $\left(M_{\mathrm{n}} 3000-5000\right)$. The conversion rates, although slower than related amido and alkyl species, were different for monomeric and dimeric initiators. The size of the metal centre also affected the conversions and the molecular weights achieved.

\section{Introduction}

The controlled ring-opening polymerization (ROP) of lactones has been extensively studied in recent years, particularly as these reactions yield biodegradable polymers. Various metal complexes such as aluminium, ${ }^{1}$ titanium, ${ }^{2}$ tin, ${ }^{3}$ zinc $^{4}$ and magnesium ${ }^{5}$ have been used as initiators for ROP of $\varepsilon$-caprolactone $(\varepsilon-\mathrm{CL})$. In 1992, McLain and Drysdale showed that the polymerization of $\varepsilon$-caprolactone initiated by rare earth alkoxides had some living character, but the molecular weight distribution of poly $(\varepsilon-$ caprolactone) got broader after the monomer was completely consumed, which suggested transesterification to be occurring. ${ }^{6}$ These transesterifications are rather common during the polymerization of $\varepsilon$-CL by metal alkoxides, and the rate at which they occur relates to both the nature of the metal ion and the groups surrounding the ion. Subsequently, it was shown that stericallydemanding groups attached to a rare earth ion can prevent poly $(\varepsilon-$ caprolactone) chains from co-coordinating to the ion and, therefore, minimise transesterification reactions. ${ }^{7}$ Since then, many rare

${ }^{a}$ Department of Chemistry, University of York, Heslington, York, UK YO10 $5 D D$

${ }^{b}$ G. A. Razuvaev Institute of Organometallic Chemistry of Russian Academy of Sciences, Tropina str. 49, 603950, Nizhny Novgorod, Russia. E-mail: trif@, imoc.sinn.ru

'Department of Chemistry, Memorial University of Newfoundland, St. John's, NL A1B 3X7, Canada. E-mail: fkerton@mun.ca; Fax: +1-7097373702

$\dagger$ Electronic supplementary information (ESI) available: ${ }^{1} \mathrm{H}$ NMR spectra of selected polymer samples. CCDC reference numbers 676933 and 676934. For crystallographic data in CIF or other electronic format see DOI: $10.1039 / \mathrm{b} 802219 \mathrm{~d}$ earth systems containing sterically-demanding ligands have been developed and studied for the controlled ROP of $\varepsilon$-CL and lactide, including bis(phosphanyl)amide, ${ }^{8}$ iminophenolato, ${ }^{9}$ pyridyl amido, ${ }^{10}$ pyridylmethyl indenyl, ${ }^{11}$ bis(phenolate),${ }^{12}$ guanidino, ${ }^{13}$ guanidinate, ${ }^{14}$ or amine(phenolate), ${ }^{15}$ and diamide-diamine ligands. ${ }^{16}$ It has been shown through this extensive research that the behaviour of lanthanide complexes for the living ROP of $\varepsilon-\mathrm{CL}$ can be tuned by altering the ancillary ligands attached to the metal centre. It has also been shown that the size of the central metal ion in these lanthanide based initiator systems also plays a crucial role in their design. ${ }^{17,18}$

Important questions about the mechanism of polymerization still need to be answered in order to clarify the relationships between the structure and activity of well-defined initiators so that improvements can be made. When a series of heteroleptic and homoleptic 2,5-bis( $N$-aryliminomethyl) pyrrolyl complexes of Y were prepared, ${ }^{19}$ the heteroleptic mono(pyrrolyl) and bis(pyrrolyl) complexes were found to be initiators for ROP of $\varepsilon$-CL, giving polyesters with moderate molecular weight distributions. The polymer made using the mono(pyrrolyl) complex, which has two amido groups, was inferior in its polydispersity $\left(M_{\mathrm{w}} / M_{\mathrm{n}}=2.0\right)$ to that made by the bis(pyrrolyl) complex $\left(M_{\mathrm{w}} / M_{\mathrm{n}}=1.3\right)$, with one amido group, indicating that the number of $\mathrm{Y}-\mathrm{N}\left(\mathrm{SiMe}_{3}\right)_{2}$ bonds significantly affects molecular weight distribution. The bis(pyrrolyl) complex acted as a single site initiator. The homoleptic tris(pyrrolyl) complexes containing no amido groups were inactive in the ROP of $\varepsilon$-CL. Therefore, the balance between reactive bonds and inert bonds within a complex needs to be properly understood in the development of new initiators. After our initial studies in this area, ${ }^{18}$ we were concerned about the reactivity of 
Ln-phenolate bonds towards lactone monomers, especially as it had already been shown that shown Ln-O containing complexes, such as alkoxide based initiators formed in situ, ${ }^{20}$ are also active species. Indeed, Visseaux and co-workers have provided evidence of $\mathrm{Ln}-\mathrm{O}$ bonds being active in the polymerization process and proposed that $\mathrm{Ln}-\mathrm{N}$ bonds are converted to such species by reaction with $\varepsilon$-CL. ${ }^{21}$ In that work, it was proposed that $\mathrm{N}\left(\mathrm{SiMe}_{3}\right)_{2}$ extracts a proton in the $\alpha$ position of the carbonyl group of $\varepsilon$-CL causing the alkoxide-Sm species to precipitate, with the $\mathrm{Sm}-\mathrm{O}$ bond being active in the polymerization process.

In this paper, we present the synthesis and $\varepsilon$-CL ROP activity of amine-bis(phenolate) lanthanide chloride complexes (see Fig. 1 for the ligands used in this work). These results indicate that although $\mathrm{Ln}$-phenolate and $\mathrm{Ln}$-amine bonds are relatively inertcompared to $\mathrm{Ln}-\mathrm{NR}_{2}$ and $\mathrm{Ln}-\mathrm{OR}$ bonds in amine-bis(phenolate) lanthanide amido and alkoxide complexes - they are not completely unreactive and may contribute low molecular weight cyclic polyester by-products in ROP reactions.<smiles>[R][R16](=O)OC[N+](=O)[O-]</smiles>

Fig. 1 Protio ligands used in this work $(t-\mathrm{Pe}=$ tert-pentyl).

\section{Results and discussion}

\section{Syntheses and structures of $\mathrm{Ln}-\mathrm{Cl}$ complexes}

We have previously reported the synthesis of lithium diamine-bis(phenolate) complexes and used these to prepare $\mathrm{Y}\left(\mathrm{O}_{2} \mathrm{NN}^{t-\mathrm{Bu}}\right) \mathrm{Cl}(\mathrm{THF})$ by a salt metathesis route. ${ }^{22}$ This approach can be extended to other rare earth metal centres, namely $\mathrm{La}, \mathrm{Pr}$, $\mathrm{Sm}, \mathrm{Gd}, \mathrm{Ho}$ and $\mathrm{Yb}$ (Scheme 1), and $\mathrm{Ln}\left(\mathrm{O}_{2} \mathrm{NN}^{\prime R}\right) \mathrm{Cl}(\mathrm{THF})$ species can be isolated as pale coloured powders in moderate yields. $\mathrm{Yb}$ and Er species have previously been prepared using sodium-ligand complexes in the salt metathesis reaction. ${ }^{15 f}$

Crystals of $\mathrm{Y}_{(}\left(\mathrm{O}_{2} \mathrm{NN}^{\prime-\mathrm{Bu}}\right) \mathrm{Cl}(\mathrm{THF})$, 1, and $\mathrm{Sm}\left(\mathrm{O}_{2} \mathrm{NN}^{t-\mathrm{Bu}}\right)$ $\mathrm{Cl}(\mathrm{DME}), 2$, suitable for $\mathrm{X}$-ray crystallographic studies were obtained by slow concentration of toluene solutions at room temperature. Complex $\mathbf{1}$ crystallizes in such a way that two crystallographically distinct molecules are present in the asymmetric unit cell, whereas complex $\mathbf{2}$ crystallizes as the toluene solvate $\mathrm{Sm}\left(\mathrm{O}_{2} \mathrm{NN}^{t-\mathrm{Bu}}\right) \mathrm{Cl}(\mathrm{DME}) \cdot 0.5\left(\mathrm{C}_{7} \mathrm{H}_{8}\right)$. The geometric parameters of the independent molecules of $\mathbf{1}$ are very similar. Crystal data for $\mathbf{1}$ and $\mathbf{2}$ are shown in Table 1. The molecular structures
Table 1 Details of crystallographic data and refinements for $\mathbf{1}$ and $\mathbf{2}$

\begin{tabular}{|c|c|c|}
\hline & 1 & $2 \cdot 0.5\left(\mathrm{C}_{7} \mathrm{H}_{8}\right)$ \\
\hline Chemical formula & $\mathrm{C}_{38} \mathrm{H}_{62} \mathrm{ClN}_{2} \mathrm{O}_{3} \mathrm{Y}$ & $\mathrm{C}_{41.50} \mathrm{H}_{68} \mathrm{ClN}_{2} \mathrm{O}_{4} \mathrm{Sm}$ \\
\hline Formula weight & 719.26 & 844.78 \\
\hline$T / \mathrm{K}$ & $100(2)$ & $100(2)$ \\
\hline Crystal system & Monoclinic & Monoclinic \\
\hline Space group & $C 2 / c$ & $P 2(1) / c$ \\
\hline$a / \AA$ & $48.516(1)$ & $12.6169(4)$ \\
\hline$b / \AA$ & $11.9131(3)$ & $19.9748(6)$ \\
\hline$c / \AA$ & $35.937(1)$ & $17.6003(5)$ \\
\hline$\beta /^{\circ}$ & $130.934(1)$ & $94.044(1)$ \\
\hline$Z$ & 16 & 4 \\
\hline$D_{\mathrm{c}} / \mathrm{Mg} \mathrm{m}^{-3}$ & 1.218 & 1.268 \\
\hline$\mu / \mathrm{mm}^{-1}$ & 1.590 & 1.425 \\
\hline$F(000)$ & 6144 & 1768 \\
\hline$\theta$ Range for collection $/^{\circ}$ & $1.68 / 26.00$ & $1.91 / 25.00$ \\
\hline No. of reflns colld & 46613 & 24314 \\
\hline No. of indep. reflns & 15386 & 7752 \\
\hline$R$ (int) & 0.0436 & 0.0224 \\
\hline$R[I>2 \sigma(I)]$ & 0.0398 & 0.0259 \\
\hline$w R$ & 0.0820 & 0.0636 \\
\hline GOOF on $F^{2}$ & 0.981 & 1.009 \\
\hline $\begin{array}{l}\text { Largest diff. peak and } \\
\text { hole } / \mathrm{e} \AA^{-3}\end{array}$ & 0.531 and -0.364 & 1.367 and -0.523 \\
\hline
\end{tabular}

of 1 and 2, Fig. 2 and 3, reveal monomeric species with the rare earth metal centres in distorted octahedral and capped trigonal prismatic environments, respectively. The $\mathrm{Y}-\mathrm{O}$ bond lengths in 1 (2.1360(10), 2.1467(10) and 2.1300(10), 2.1492(10) $\AA$ ) are close to the values previously reported for six-coordinate bis(phenolate), ${ }^{23 a, b}$ aminophenolate, ${ }^{23 c}$ and salicylaldiminate ${ }^{23 d, e}$ yttrium complexes. The $\mathrm{O}-\mathrm{Y}-\mathrm{O}$ bond angle in $\mathbf{1}$ (152.88(3) and $\left.153.24(3)^{\circ}\right)$ is slightly larger than that in a related six-coordinate alkylyttrium compound $\left(150.94(7)^{\circ}\right) .{ }^{15 d}$ In general, the structure of $\mathbf{1}$ is similar to other monomeric $\mathrm{Y}$ complexes containing these or similar ligands, ${ }^{15 c, d}$ and the $\mathrm{Sc}$ complex, $\mathrm{Sc}\left(\mathrm{O}_{2} \mathrm{NPy}^{t-\mathrm{Bu}}\right)(\mathrm{Cl})(\mathrm{py}){ }^{23 c}$ 1 is isostructural with the previously reported $\mathrm{Yb}$ and $\mathrm{Er}$ analogues. ${ }^{15 f}$ As expected the Ln-phenoxide bonds are marginally longer in $\mathbf{1}$ due to the larger ionic radius of $\mathrm{Y}^{3+}$ compared with $\mathrm{Yb}^{3+}$ and $\mathrm{Er}^{3+}$.

The monomeric structure of $\mathbf{2}$ is somewhat more surprising and is in contrast to the dimeric structure of the related Gd complex, $\left[\left\{\mathrm{Gd}\left(\mathrm{O}_{2} \mathrm{NN}^{\prime \prime-\mathrm{Pe}}\right)(\mathrm{THF})(\mu-\mathrm{Cl})\right\}_{2}\right]{ }^{18}$ the La complex, $\left[\left\{\mathrm{La}\left(\mathrm{O}_{2} \mathrm{NPy}^{t-\mathrm{Bu}}\right)(\mu-\mathrm{Cl})\right\}_{2}\right]$ and $\mathrm{Sm}$ complex, $\left[\left\{\mathrm{Sm}\left(\mathrm{O}_{2} \mathrm{NPy}^{t-\mathrm{Bu} u}\right)(\mu-\right.\right.$ $\left.\mathrm{Cl})\}_{2}\right]_{.15 b}$ Although, the use of a dibasic co-solvent, DME, in the recrystallization process and the resultant formation of a sevencoordinate $\mathrm{Sm}$ centre may have aided in its isolation. The $\mathrm{Sm}-\mathrm{O}$ bond distances in 2 (2.1819(13), 2.2113(14) A) fall into the interval normally observed for seven-coordinate samarium phenoxides. ${ }^{23, g}$

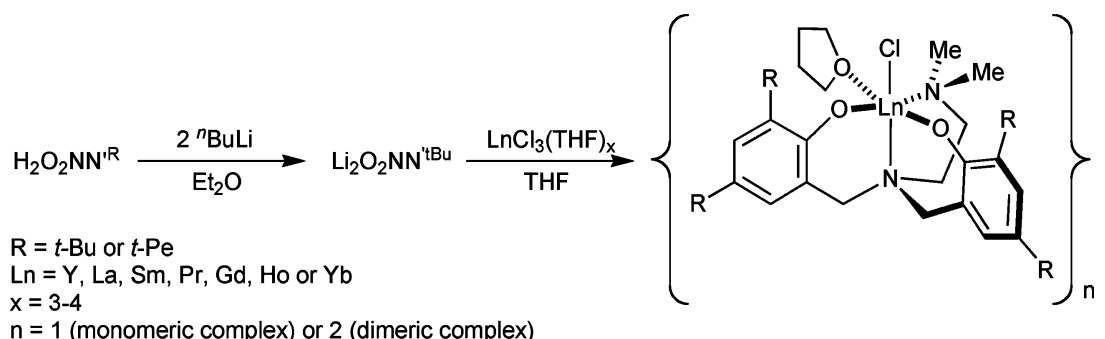

Scheme 1 Synthesis of chlorobis(phenolate)diamine complexes of lanthanides. 


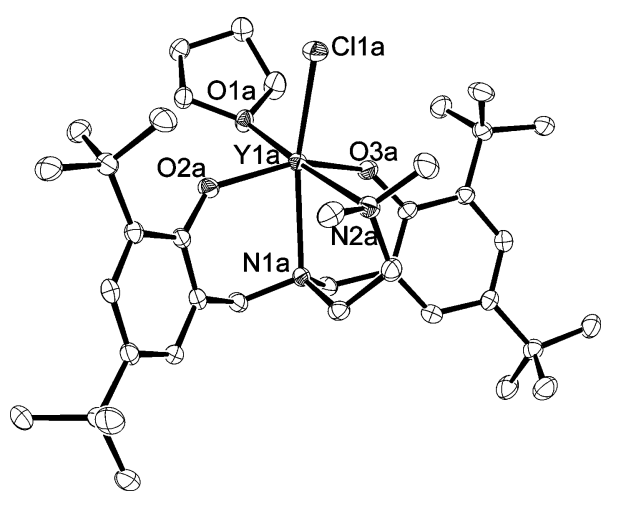

Fig. 2 Molecular structure of $\mathrm{Y}\left(\mathrm{O}_{2} \mathrm{NN}^{t-\mathrm{Bu}}\right) \mathrm{Cl}(\mathrm{THF}), 1, \mathrm{H}$ atoms are omitted for clarity. Two molecules are present in the asymmetric unit cell, molecule $\mathrm{A}$ is shown. Thermal ellipsoids are drawn at the $20 \%$ probability level. Selected bond lengths $(\AA)$ ) and angles $\left(^{\circ}\right)$ for both molecules: $\mathrm{Y}(1 \mathrm{~A})-\mathrm{O}(2 \mathrm{~A}) 2.136(1), \mathrm{Y}(1 \mathrm{~A})-\mathrm{O}(3 \mathrm{~A})$ 2.147(1), $\mathrm{Y}(1 \mathrm{~A})-\mathrm{O}(1 \mathrm{~A})$ 2.343(1), $\mathrm{Y}(1 \mathrm{~A})-\mathrm{N}(1 \mathrm{~A}) 2.515(1), \mathrm{Y}(1 \mathrm{~A})-\mathrm{N}(2 \mathrm{~A}) 2.552(1), \mathrm{Y}(1 \mathrm{~A})-\mathrm{Cl}(1 \mathrm{~A})$ $2.5725(3), \quad \mathrm{O}(2 \mathrm{~A})-\mathrm{Y}(1 \mathrm{~A})-\mathrm{O}(3 \mathrm{~A}) \quad 152.88(3), \quad \mathrm{N}(1 \mathrm{~A})-\mathrm{Y}(1 \mathrm{~A})-\mathrm{N}(2 \mathrm{~A})$ 70.61(4); $\quad \mathrm{Y}(1 \mathrm{~B})-\mathrm{O}(2 \mathrm{~B}) \quad 2.1300(10), \quad \mathrm{Y}(1 \mathrm{~B})-\mathrm{O}(3 \mathrm{~B}) \quad 2.1492(10)$, $\mathrm{Y}(1 \mathrm{~B})-\mathrm{O}(1 \mathrm{~B}) \quad 2.3343(12), \quad \mathrm{Y}(1 \mathrm{~B})-\mathrm{N}(1 \mathrm{~B}) \quad 2.5216(10), \quad \mathrm{Y}(1 \mathrm{~B})-\mathrm{N}(2 \mathrm{~B})$ 2.5437(4), $\quad \mathrm{Y}(1 \mathrm{~B})-\mathrm{Cl}(1 \mathrm{~B}) \quad 2.5769(3), \quad \mathrm{O}(2 \mathrm{~B})-\mathrm{Y}(1 \mathrm{~B})-\mathrm{O}(3 \mathrm{~B}) \quad$ 153.24(3), $\mathrm{N}(1 \mathrm{~B})-\mathrm{Y}(1 \mathrm{~B})-\mathrm{N}(2 \mathrm{~B}) 70.59(3)$.

As far as we are aware, this is the first monomeric samarium chloride amine-bis(phenolate) complex reported.

\section{Reactivity of $\mathrm{Ln}-\mathrm{Cl}$ complexes towards \&-caprolactone}

At first, we thought that the lanthanide-chloride complexes, $\mathrm{Ln}\left(\mathrm{O}_{2} \mathrm{NN}^{\prime \mathrm{R}}\right) \mathrm{Cl}(\mathrm{THF})$, would not initiate the polymerization of $\varepsilon-\mathrm{CL}$, as using the same conditions as those employed with lanthanide-amido initiators, polymerization did not occur. ${ }^{18}$ In several previously reported studies, ${ }^{15,18,23}$ these and related complexes appear to be fluxional in solution between dimeric and monomeric forms, possibly resulting in there being no free coordination sites for the incoming ester to coordinate. However, during attempts to isolate $\mathrm{Ln}$-caprolactone adducts, it was discovered that over a longer reaction time, ROP of $\varepsilon$-CL could be brought about using these complexes as initiators. Therefore, a series of polymerization reactions were conducted in parallel, using stirred vials in a nitrogen filled glove box. The chosen lanthanides

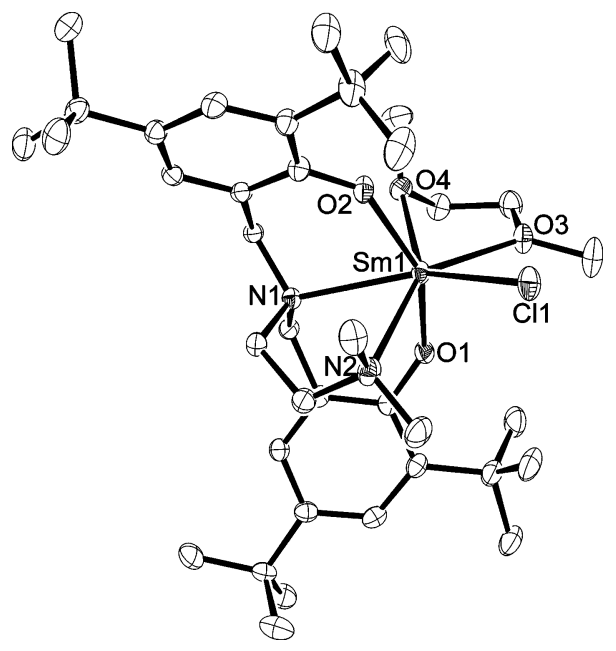

Fig. 3 Molecular structure of $\mathrm{Sm}\left(\mathrm{O}_{2} \mathrm{NN}^{\prime t-\mathrm{Bu}}\right) \mathrm{Cl}(\mathrm{DME}), 2, \mathrm{H}$ atoms are omitted for clarity. Thermal ellipsoids are drawn at the $20 \%$ probability level. Selected bond lengths (Å) and angles $\left({ }^{\circ}\right)$ : $\mathrm{Sm}(1)-\mathrm{O}(2)$ 2.182(1), Sm(1)-O(1) 2.211(1), Sm(1)-O(4) 2.546(1), Sm(1)-N(1) 2.624(2), $\mathrm{Sm}(1)-\mathrm{O}(3) \quad 2.629(1), \quad \mathrm{Sm}(1)-\mathrm{Cl}(1) \quad 2.6792(5), \quad \mathrm{Sm}(1)-\mathrm{N}(2) \quad 2.685(2)$, $\mathrm{O}(2)-\mathrm{Sm}(1)-\mathrm{O}(1)$ 150.34(5), N(1)-Sm(1)-N(2) 68.10(5).

represented a range of metal sizes across the lanthanide series, and were used in combination with ligand $\left(\mathrm{O}_{2} \mathrm{NN}^{t-\mathrm{Pe}}\right)^{2-}$. This $t$ Pe substituted ligand was chosen in preference to $\left(\mathrm{O}_{2} \mathrm{NN}^{\prime t-\mathrm{Bu}}\right)^{2-}$ for these reactions as slightly narrower molecular weight distributions were afforded by complexes bearing this ligand in our previous study. ${ }^{18}$ The reaction time was increased from $1 \mathrm{~h}$ to $24 \mathrm{~h}$ (Table 2). These data contrast with results obtained for the related Sm species, $\left[\left\{\mathrm{Sm}\left(\mathrm{O}_{2} \mathrm{NPy}{ }^{t-\mathrm{Bu}}\right)(\mu-\mathrm{Cl})\right\}_{2}\right]$, which did not yield any polymer after $16 \mathrm{~h}$ reaction time. ${ }^{15 b}$ This shows that small changes to the amine-bis(phenolate) ligand can result in quite significant changes in reactivity. No attempts were made to investigate ROP of lactide using the chloride complexes that we have reported here.

There are a number of mechanisms by which these polymerizations could be proceeding. One possibility is via insertion of the monomer into the metal-phenoxide bond, as has been proposed for Sm tris(phenolate) species. ${ }^{28}$ In previous studies of ROP using amine-bis(phenolate) Ln species, the Ln-phenolate bonds were considered inert and the monomer only inserted into the metal

Table 2 Polymerization of $\varepsilon$-caprolactone initiated by lanthanide-chloride complexes, $\operatorname{Ln}\left(\mathrm{O}_{2} \mathrm{NN}^{\prime \prime-\mathrm{Pe}}\right) \mathrm{Cl}(\mathrm{THF})$

\begin{tabular}{lccc}
\hline Metal & $\%$ Conversion $^{a}$ & $M_{\mathrm{w}} / M_{\mathrm{n}}{ }^{b}$ & $M_{\mathrm{n}}{ }^{b}$ \\
\hline $\mathrm{Pr}$ & 91 & 1.3 & $7390(4138)$ \\
$\mathrm{Sm}$ & 92 & 1.9 & $8130(4550)$ \\
$\mathrm{Gd}$ & 74 & 1.2 & $7720(4323)$ \\
$\mathrm{Ho}$ & $29(35)^{c}$ & 1.3 & $7540(4222)$ \\
$\mathrm{Y}$ & $89(100)^{c}$ & 1.6 & $7890(4418)$ \\
$\mathrm{Yb}$ & 7 & 1.1 & $5200(2912)$ \\
$\mathrm{Sm}\left(\mathrm{N}^{\prime \prime}\right)_{3}+\left[\mathrm{O}_{2} \mathrm{NN}^{\prime-\mathrm{Pe}}\right] \mathrm{H}_{2}{ }^{d}$ & 100 & 1.2 & $79300(44,408)$ \\
$\mathrm{Gd}\left(\mathrm{N}^{\prime \prime}\right)_{3}+\left[\mathrm{O}_{2} \mathrm{NN}^{\prime t-\mathrm{Pe}}\right] \mathrm{H}_{2}{ }^{d}$ & 100 & 1.7 & $70900(39,704)$ \\
$\mathrm{Y}\left(\mathrm{N}^{\prime \prime}\right)_{3}+\left[\mathrm{O}_{2} \mathrm{NN}^{\prime-\mathrm{Pe}}\right] \mathrm{H}_{2}{ }^{d}$ & 80 & 1.2 & $13100(7,336)$ \\
$\left.\left[\mathrm{Sm}_{2}\left(\mathrm{O}_{2} \mathrm{NPy}^{t-\mathrm{Bu}}\right)(\mu-\mathrm{Cl})\right\}_{2}\right]$ & $0^{e}$ & $\mathrm{n} / \mathrm{a}$ & $\mathrm{n} / \mathrm{a}$ \\
$\mathrm{YCl}_{3}(\mathrm{THF})_{3}$ & $0^{d}$ & $\mathrm{n} / \mathrm{a}$ & $\mathrm{n} / \mathrm{a}$
\end{tabular}

${ }^{a}$ Calculated using ${ }^{1} \mathrm{H}$ NMR spectroscopy, polymerization reaction time $24 \mathrm{~h} .{ }^{b} \mathrm{GPC}$ analysis. Corrected $M_{\mathrm{n}}$ values with the coefficient 0.56 in parentheses. ${ }^{25}$ ${ }^{c}$ Values in parentheses are for duplicate reactions performed with different batches of initiator. ${ }^{d}$ Data from previous studies using in situ generated amido species, polymerization time $1 \mathrm{~h} .{ }^{18}$ e Data from previous studies using a pyridyl substituted amine-(bis)phenolate ligand..$^{15 b}$ 


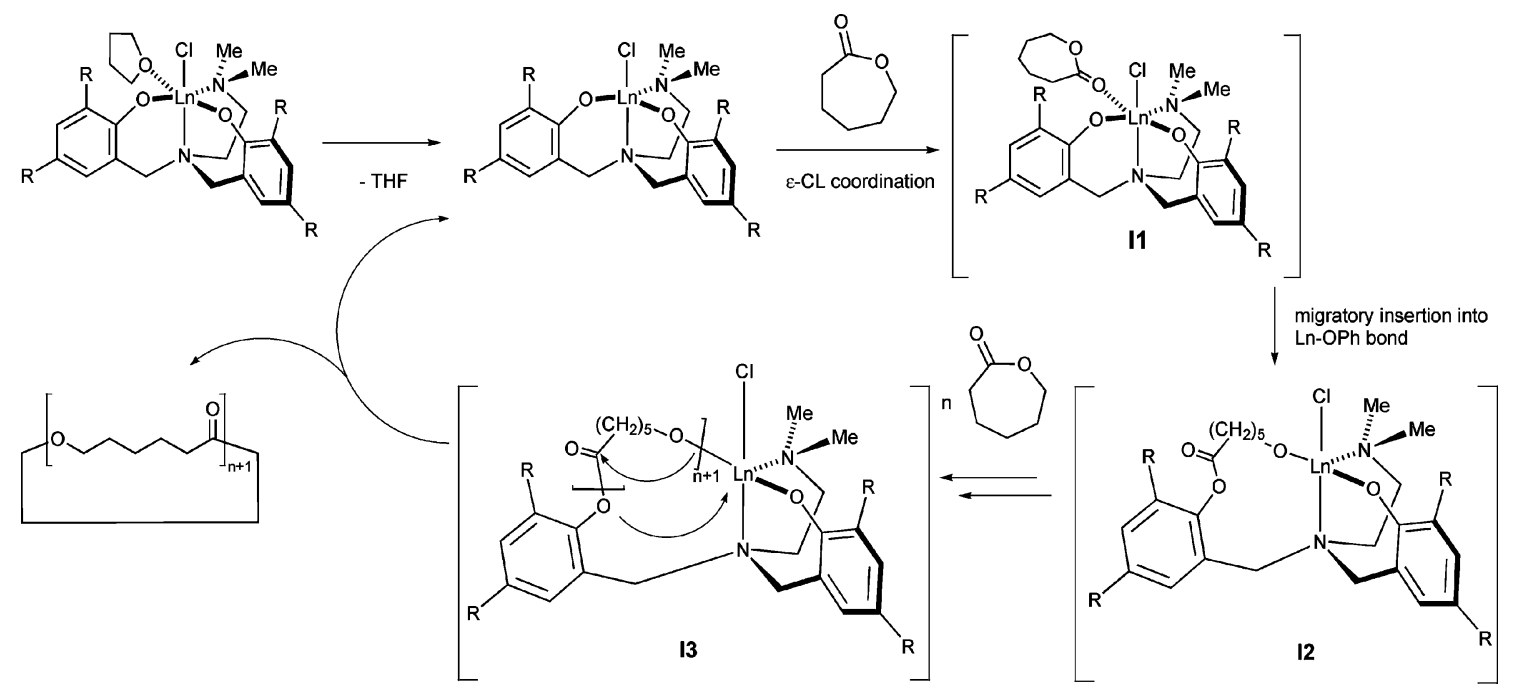

Scheme 2 Proposed mechanism of $\varepsilon$-caprolactone ROP by $\operatorname{Ln}\left(\mathrm{O}_{2} \mathrm{NN}^{\prime R}\right) \mathrm{Cl}(\mathrm{THF})$ species.

amide or alkyl bond in these related lanthanide-amide and alkyl lactone ROP initiators. ${ }^{15,18}$ However, in our study no ligand related end groups that would suggest this insertion mechanism were observed in the ${ }^{1} \mathrm{H}$ NMR spectra of the polymer products. Another possible mechanism is via Lewis acid catalysis, which is the mechanism employed by widely used tin(II) species including stannous octoate. ${ }^{29}$ In such processes, polymerization is thought to occur through transesterification reactions between the activated lactone (metal coordinated lactone, similar to I1, Scheme 2) and hydroxyl groups. The hydroxyl groups can originate from an added initiator to yield designer end-functionalized $\mathrm{P}(\varepsilon-\mathrm{CL}),{ }^{29 d-f}$ or through reaction contaminants or water. This is unlikely the case for our complexes, as ${ }^{1} \mathrm{H}$ NMR spectra of the polymers do not show the expected and distinctive terminal $-\mathrm{CH}_{2} \mathrm{OH}$ resonances. Therefore, we are likely forming cyclic polyesters as have been reported with other initiators. ${ }^{15 e, 26,30}$ Unfortunately, at the time of this study, we were unable to perform MALDI-TOF MS analyses on the polymer samples to prove this unequivocally. This cyclic ester formation may be occuring by one of two coordination-insertion mechanisms, both proceed via an $\varepsilon-\mathrm{CL}$ adduct intermediate such as I1, Scheme 2. Initiation may occur via migratory insertion into the Ln-phenolate bond or through ring-opening attack by the proximal $-\mathrm{NMe}_{2}$ group. Propogation would then proceed via a slightly different coordination-insertion mechanism for each type of initiation, followed by similar ringclosing/termination steps to yield the cyclic polymer. The latter type of ROP of $\varepsilon$-CL facilitated by a Ln metal centre and attack of an amine or amide functional group within an ancillary ligand has previously been proposed by the groups of Okuda, ${ }^{30}$ and Mountford. ${ }^{15 e}$ In both these cases, the resultant polymer was cyclic.

It is worth noting that the activity of the $\mathrm{Yb}$ species is significantly lower than the other complexes studied, presumably because of the smaller ion size and a reduced ability to form the necessary intermediate, I1. The smaller size of the $\mathrm{Yb}^{3+}$ ion may also have led to the lower molecular weight for the polymers it yielded. It is, however, somewhat surprising to find that $\mathrm{Y}$, being close to Ho in size, demonstrated such a high activity. These polymerization reactions were repeated using freshly synthesised
$\mathrm{Y}\left(\mathrm{O}_{2} \mathrm{NN}^{t-\mathrm{Pe}}\right) \mathrm{Cl}(\mathrm{THF})$ and $\mathrm{Ho}\left(\mathrm{O}_{2} \mathrm{NN}^{\prime t-\mathrm{Pe}}\right) \mathrm{Cl}(\mathrm{THF})$ to confirm these observations. This result suggests that electronic factors do also play a role in determining the polymerization activity of the complex. The smallest of the metals, $\mathrm{Yb}$, gave a polymer with the narrowest polydispersity, perhaps owing to a reduced possibility of side reactions such as transesterification. A clear trend between the polydispersities and metal size is not evident in these reactions. This may be attributed to the different extents to which the complexes fluctuate between monomer and dimer in solution, so the number and type of active sites are not constant. To assess the affect of monomer-dimer equilibria on this process, polymerization reactions initiated by $\left\{\mathrm{Gd}\left(\mathrm{O}_{2} \mathrm{NN}^{\prime t-\mathrm{Pe}}\right)(\mathrm{THF})(\mu\right.$ $\mathrm{Cl})\}_{2}$ and $\mathrm{Y}_{2}\left(\mathrm{O}_{2} \mathrm{NN}^{t-\mathrm{Pe}}\right) \mathrm{Cl}(\mathrm{THF})$ were monitored over time using ${ }^{1} \mathrm{H}$ NMR spectroscopy, Fig. 4. Very different reaction profiles for each initiator were revealed. When polymerization was initiated by $\mathrm{Y}\left(\mathrm{O}_{2} \mathrm{NN}^{\prime-\mathrm{Pe}}\right) \mathrm{Cl}(\mathrm{THF})$, the initial rate of conversion is far greater compared to the Gd species. This suggests that the smaller metal, $\mathrm{Y}$, does not dimerize as readily as $\mathrm{Gd}$, as it is sufficiently shielded by the bulky ligand and perhaps, only exists in its monomeric form in solution so initiates polymerization more rapidly. Interestingly,

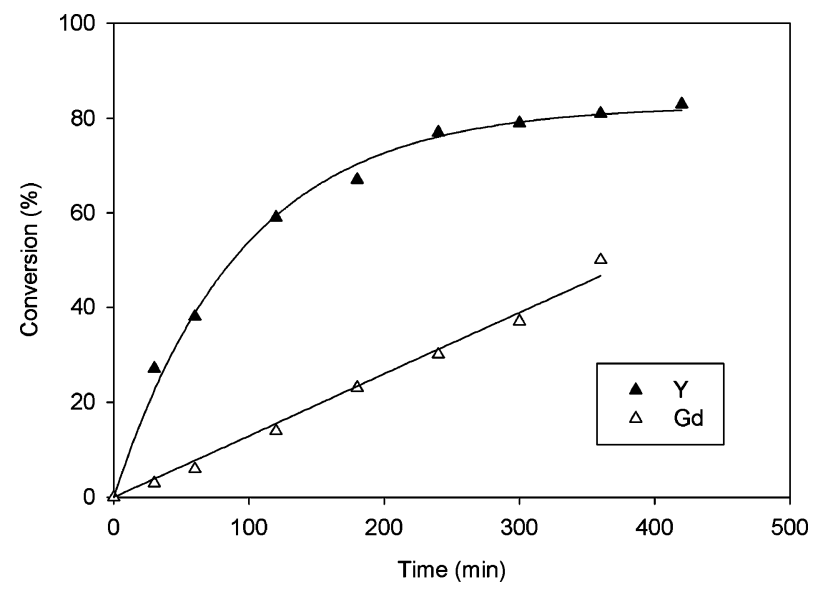

Fig. 4 Polymerization of $\varepsilon$-caprolactone by $\mathrm{Y}\left(\mathrm{O}_{2} \mathrm{NN}^{\prime t-\mathrm{Pe}}\right) \mathrm{Cl}(\mathrm{THF})\left(\right.$ fit $r^{2}=$ $0.988)$ and $\left[\left\{\mathrm{Gd}\left(\mathrm{O}_{2} \mathrm{NN}^{t-\mathrm{Pe}}\right)(\mathrm{THF})(\mu-\mathrm{Cl})\right\}_{2}\right]\left(\right.$ fit $\left.r^{2}=0.995\right)$. 
when employing $\left\{\mathrm{Gd}\left(\mathrm{O}_{2} \mathrm{NN}^{\prime \prime-\mathrm{Pe} e}\right)(\mathrm{THF})(\mu-\mathrm{Cl})\right\}_{2}$ as the initiator, the reaction appears to be zero order in $\varepsilon$-CL giving a linear conversion vs. time plot. This difference, compared to the results from $\mathrm{Y}\left(\mathrm{O}_{2} \mathrm{NN}^{\prime \prime-\mathrm{Pe}}\right) \mathrm{Cl}(\mathrm{THF})$, is once again presumably due to differences in the solution-state structures between these two related species. It is also noted that for $\mathrm{Y}\left(\mathrm{O}_{2} \mathrm{NN}^{\prime t-\mathrm{Pe} e}\right) \mathrm{Cl}(\mathrm{THF})$, the plot of $\ln \left([\varepsilon-\mathrm{CL}]_{0} /[\varepsilon-\mathrm{CL}]_{t}\right) v s$. time was not linear (fit $r^{2}=0.88$ ), unlike many other lactone ROP initiators. ${ }^{24,25}$ Given the variety of coordination-insertion mechanisms that are possible using these initiators, it may be that the $\mathrm{Y}$ species facilitates the ROP by a different mechanism to its $\mathrm{Gd}$ analogue.

One possible polymerization mechanism for our systems is shown in Scheme 2. $\varepsilon$-CL adducts related to $\mathbf{I 1}, \mathrm{LnCl}_{3}(\varepsilon-\mathrm{CL})_{3}$, have been isolated and structurally characterized by Evans and co-workers. ${ }^{27}$ Samarium tris(phenolate) complexes have recently been reported as initiators for $\varepsilon$-CL ROP and their mechanism studied in some detail. ${ }^{28}$ It was proposed that $\varepsilon$-CL insertion occurs at all three $\mathrm{Sm}-\mathrm{O}$ bonds and although in Scheme 2 insertion is only shown into one $\mathrm{Ln}-\mathrm{O}$ bond, it may well be occuring at both reactive bond sites. After repeated coordination and migratory-insertion steps, termination is likely occuring via nucleophilic attack of the 'phenol' oxygen at the Ln metal centre and subsequent 'back-biting' of the growing polymer chain to yield cyclic polyesters of narrow polydispersity. The narrow range of low molecular weights afforded by all our systems $(n=25-40)$ suggests the size of the chelate rings in I2 and I3 are important in mediating and moderating the polymerization process, especially when compared with other lanthanide aminebis(phenolate) species that generally afford higher molecular weight polymers. ${ }^{15,18}$ The presence of the pendant $\mathrm{NMe}_{2}$ group and the resulting 5-membered $\mathrm{Ln}-\mathrm{NCH}_{2} \mathrm{CH}_{2} \mathrm{~N}$ ring is likely crucial to the activity of these species, given related pyridyl species do not initiate polymerization. ${ }^{15 b}$ The generally slow but high conversions to afford cyclic low molecular weight polyesters with a narrow molecular weight distribution suggests a key role for the metal centre and resulting chelate size which restricts the chain (ring) growth in these systems. Although organic catalysts for ROP of lactones have recently been discovered, ${ }^{26}$ the protio ligands in this study do not initiate polymerization nor do $\operatorname{Ln}(\mathrm{Cl})_{3} \mathrm{THF}_{x}$ reagents. However, many metal complexes bearing these amine bis-phenolate ligands (as discussed above) are known to initiate $\varepsilon$ $\mathrm{CL}$ and lactide polymerization. Some of these such as lithium, barium, calcium and $\mathrm{Ln}^{2+}$ species only contain $\mathrm{M}$-phenolate bonds around the metal centre and therefore, may initiate lactone ROP via a similar coordination-insertion mechanism to those proposed here. ${ }^{24,31}$ Clearly, there is still a significant amount of mechanistic study needed to fully understand the ROP activity of these and related complexes, and that several mechanisms may even be occurring simultaneously (despite the low $M_{\mathrm{w}} / M_{\mathrm{n}}$ of the polymers).

\section{Experimental}

\section{General procedures}

All manipulations were performed under an atmosphere of dry oxygen-free nitrogen or argon by means of standard Schlenk line or glove box techniques unless otherwise stated. Analytical grade solvents were purchased from Fisher and distilled from sodium benzophenone (diethyl ether, hexane, pentane, THF, toluene) under argon. Transfer of dry oxygen-free solutions was carried out using cannula or vacuum transfers. Deuterated benzene, toluene and pyridine were dried by stirring over potassium metal. The deuterated solvents were then freeze-pump-thaw degassed and trap-to-trap distilled. $\mathrm{LaCl}_{3} \cdot 6 \mathrm{H}_{2} \mathrm{O}, \mathrm{PrCl}_{3} \cdot 6 \mathrm{H}_{2} \mathrm{O}, \mathrm{SmCl}_{3} \cdot 6 \mathrm{H}_{2} \mathrm{O}$, $\mathrm{GdCl}_{3} \cdot 6 \mathrm{H}_{2} \mathrm{O}, \mathrm{HoCl}_{3} \cdot 6 \mathrm{H}_{2} \mathrm{O}, \mathrm{YCl}_{3} \cdot 6 \mathrm{H}_{2} \mathrm{O}$, and $\mathrm{YbCl}_{3} \cdot 6 \mathrm{H}_{2} \mathrm{O}$ were purchased from Strem and converted to the $\mathrm{LnCl}_{3}(\mathrm{THF})_{x}$ species using literature procedures. ${ }^{32}$ Diamine-bis(phenol) ligands were prepared in methanol, ethanol or water following literature procedures. ${ }^{33} \varepsilon$-CL was dried over $\mathrm{CaH}_{2}$ and trap-to-trap distilled prior to use. NMR spectra were recorded on a Jeol EX 270 instrument or Bruker AMX-500 or Avance-500 instruments. ${ }^{1} \mathrm{H}$ NMR spectra were referenced to residual protons in the deuterated solvent and ${ }^{13} \mathrm{C}$ NMR spectra to the residual ${ }^{13} \mathrm{C}$ atoms of the solvent. Elemental analyses were performed by Elemental Microanalysis Ltd., Devon or Guelph Chemical Laboratories, Canada. GPC analyses were performed by Rapra Technology Ltd., Shrewsbury. The GPC system was calibrated with narrow distribution polystyrene calibrants obtained from Polymer Laboratories Ltd. Analyses were made on chloroform solutiuons at $30{ }^{\circ} \mathrm{C}$ using a refractive index detector.

\section{X-Ray crystallography}

Low-temperature diffraction data were collected on a BrukerAXS Smart Apex I diffractometer with graphite-monochromated Mo- $\mathrm{K}_{a}$ radiation $(\lambda=0.71073 \AA)$. All structures were solved by direct methods and refined against $F^{2}$ on all data by fullmatrix least squares with SHELXTL. ${ }^{34}$ Absorption correction was applied using SADABS. ${ }^{35}$ All non-hydrogen atoms were refined anisotropically. All hydrogen atoms in $\mathbf{1}$ and $\mathbf{2}$ were included in idealized positions and their $U_{\text {iso }}$ values were set to ride on the $U_{\text {eq }}$ values of the parent carbon atoms $\left(U_{\text {iso }}(\mathrm{H})=1.5 U_{\text {eq }}\right.$ for methyl carbons and $1.2 U_{\text {eq }}$ for other carbons). In $\mathbf{1}$, for the second independent molecule in the asymmetric unit cell, orientation disorders on two positions of $\mathrm{CH}_{2}$ and two Me groups in the $-\mathrm{CH}_{2} \mathrm{NMe}_{2}$ fragment were found. The disordered groups were refined with population of positions $0.8: 0.2$. Crystallographic data and structure refinement details are given in Table 1.

\section{General procedure for the preparation of $\mathrm{Li}_{2}\left(\mathrm{O}_{2} \mathrm{NN}^{\prime \mathrm{R}}\right)$ complexes}

This method has been optimized based on the original literature procedure. ${ }^{22}$ To a THF solution $(20 \mathrm{~mL})$ of the appropriate protonated ligand $(5.6 \mathrm{mmol})$ at $0{ }^{\circ} \mathrm{C}$ was slowly added $n \mathrm{BuLi}$ $(1.6 \mathrm{M}, 8 \mathrm{~mL}, 12.8 \mathrm{mmol})$. After stirring at $0{ }^{\circ} \mathrm{C}$ for $10 \mathrm{~min}$ and then at room temperature for $2 \mathrm{~h}$ the solvent was removed in vacuo to give an off-white solid. The solid was washed twice with pentane $(2 \times 20 \mathrm{~mL})$ at $0{ }^{\circ} \mathrm{C}$ and yielded a colourless powder. Crystals of the complex $\mathrm{Li}_{2}\left(\mathrm{O}_{2} \mathrm{NN}^{\prime \prime-\mathrm{Bu}}\right)$ suitable for $\mathrm{X}$-ray diffraction analysis can be grown by several methods. ${ }^{24,30 b}$

Data for $\mathbf{L i}_{2}\left(\mathbf{O}_{2} \mathbf{N} \mathbf{N}^{t-\mathrm{Pe}}\right)$. Yield $75 \%$. ${ }^{1} \mathrm{H}$ NMR $\left(\mathrm{C}_{5} \mathrm{D}_{5} \mathbf{N}\right.$, $500 \mathrm{MHz}, 298 \mathrm{~K}): \delta 7.34\left(\mathrm{~d},{ }^{4} J_{\mathrm{HH}}=1.70 \mathrm{~Hz}, 2 \mathrm{H}, \operatorname{Ar} H\right), 7.07$ $\left(\mathrm{d},{ }^{4} J_{\mathrm{HH}}=1.70 \mathrm{~Hz}, 2 \mathrm{H}, \operatorname{Ar} H\right), 4.28\left(\mathrm{~d},{ }^{2} J_{\mathrm{HH}}=11.70 \mathrm{~Hz}, 2 \mathrm{H}\right.$, $\operatorname{ArCHH}), 3.23\left(\mathrm{~d},{ }^{2} J_{\mathrm{HH}}=11.70 \mathrm{~Hz}, 2 \mathrm{H}, \operatorname{ArCH} H\right), 2.81\left(\mathrm{t},{ }^{3} J_{\mathrm{HH}}=\right.$ $\left.5.44 \mathrm{~Hz}, 2 \mathrm{H}, \mathrm{NCH}_{2}\right), 2.46\left(\mathrm{~m}, 2 \mathrm{H}, \mathrm{CH}_{2}\right), 2.03\left(\mathrm{t},{ }^{3} \mathrm{~J}_{\mathrm{HH}}=5.44 \mathrm{~Hz}\right.$, $\left.2 \mathrm{H}, \mathrm{NCH}_{2}\right), 1.79\left(\mathrm{~m}, 2 \mathrm{H}, \mathrm{CH}_{2}\right), 1.72\left(\mathrm{~m}, 4 \mathrm{H}, \mathrm{CH}_{2}\right), 1.66(\mathrm{~d}$, $\left.{ }^{4} J_{\mathrm{HH}}=2.62 \mathrm{~Hz}, 12 \mathrm{H}, \mathrm{CH}_{3}\right), 1.53\left(\mathrm{~s}, 6 \mathrm{H}, \mathrm{N}\left(\mathrm{CH}_{3}\right)_{2}\right), 1.39(\mathrm{~s}, 6 \mathrm{H}$, 
$\left.\mathrm{CH}_{3}\right), 1.35$ (s, $\left.6 \mathrm{H}, \mathrm{CH}_{3}\right), 0.82\left(\mathrm{~m}, 12 \mathrm{H}, \mathrm{CH}_{3}\right) \cdot{ }^{13} \mathrm{C}\left\{{ }^{1} \mathrm{H}\right\} \mathrm{NMR}$ $\left(\mathrm{C}_{5} \mathrm{D}_{5} \mathrm{~N}, 75.50 \mathrm{MHz}, 298 \mathrm{~K}\right): \delta 166.5$ (q), 136.3 (q), 130.9 (q), $128.1(\mathrm{CH}), 126.6(\mathrm{CH}), 125.3(\mathrm{q}), 68.3\left(\mathrm{CH}_{2}\right), 64.5\left(\mathrm{CH}_{2}\right), 45.5$ $\left(\mathrm{CH}_{2}\right), 39.3\left(\mathrm{CH}_{3}\right), 38.1$ (q), 37.6 (q), $32.6\left(\mathrm{CH}_{3}\right), 29.9\left(\mathrm{CH}_{3}\right)$. Anal. Found: $\mathrm{C} 77.02 ; \mathrm{H} 10.44 ; \mathrm{N}$ 4.59. $\mathrm{C}_{38} \mathrm{H}_{62} \mathrm{Li}_{2} \mathrm{~N}_{2} \mathrm{O}_{2}$ : requires C, $76.99 ; \mathrm{H}, 10.54 ; \mathrm{N}, 4.73 \%$.

Data for $\mathbf{L i}_{2}\left(\mathbf{O}_{2} \mathbf{N N} \mathbf{N}^{\prime-\mathrm{Bu}}\right)$. Yield $70 \%$. ${ }^{1} \mathrm{H}$ NMR $\left(\mathrm{C}_{5} \mathrm{D}_{5} \mathrm{~N}\right.$, $500 \mathrm{MHz}, 298 \mathrm{~K}): \delta 7.53(\mathrm{br}, 2 \mathrm{H}, \operatorname{Ar} H), 7.17(\mathrm{br}, 2 \mathrm{H}, \operatorname{Ar} H$ ), $4.20\left(\mathrm{~d},{ }^{2} J_{\mathrm{HH}}=10.2 \mathrm{~Hz}, 2 \mathrm{H}, \operatorname{ArCHH}\right), 3.09\left(\mathrm{~d},{ }^{2} J_{\mathrm{HH}}=10.2 \mathrm{~Hz}\right.$, $2 \mathrm{H}, \mathrm{ArCH} H), 2.98\left(\mathrm{br}, 2 \mathrm{H}, \mathrm{NCH}_{2}\right), 2.43\left(\mathrm{br}, 2 \mathrm{H}, \mathrm{NCH}_{2}\right), 1.64(\mathrm{br}$, $\left.18 \mathrm{H}, \mathrm{CH}_{3}\right), 1.49\left(\mathrm{br}, 6 \mathrm{H}, \mathrm{N}\left(\mathrm{CH}_{3}\right)_{2}\right), 1.45\left(\mathrm{br}, 18 \mathrm{H}, \mathrm{CH}_{3}\right) .{ }^{13} \mathrm{C}\left\{{ }^{1} \mathrm{H}\right\}$ $\operatorname{NMR}\left(\mathrm{C}_{5} \mathrm{D}_{5} \mathrm{~N}, 75.50 \mathrm{MHz}, 298 \mathrm{~K}\right): \delta 165.7$ (q), 136.8 (q), 132.5 (q), $127.6(\mathrm{CH}), 125.2(\mathrm{CH}), 122.5(\mathrm{q}), 63.7\left(\mathrm{CH}_{2}\right), 59.2\left(\mathrm{CH}_{2}\right)$, $50.9\left(\mathrm{CH}_{2}\right), 44.6\left(\mathrm{CH}_{3}\right), 35.2(\mathrm{q}), 33.7(\mathrm{q}), 32.1\left(\mathrm{CH}_{3}\right), 29.7\left(\mathrm{CH}_{3}\right)$. Anal. Found: C 76.07, H 10.41, N 5.00. $\mathrm{C}_{34} \mathrm{H}_{54} \mathrm{~N}_{2} \mathrm{O}_{2} \mathrm{Li}_{2}$ requires: C 76.09, H 10.14, N 5.22\%.

\section{General procedure for the preparation of $\operatorname{Ln}\left(\mathrm{O}_{2} \mathrm{NN}^{t-\mathrm{Pe}}\right) \mathrm{Cl}(\mathrm{THF})$ and $\operatorname{Ln}\left(\mathrm{O}_{2} \mathrm{NN}^{\prime t-\mathrm{Bu}}\right) \mathrm{Cl}(\mathrm{THF})(\mathrm{Ln}=\mathrm{Pr}, \mathrm{Sm}, \mathrm{Gd}, \mathrm{Ho}, \mathrm{Y}, \mathrm{Yb})$}

To a THF solution $(15 \mathrm{~mL})$ of $\mathrm{LnCl}_{3}(\mathrm{THF})_{x}(1.9 \mathrm{mmol})$ at $0{ }^{\circ} \mathrm{C}$ was added a THF solution $(15 \mathrm{~mL})$ of the appropriate lithiated ligand $(1.9 \mathrm{mmol})$ which was also cooled to $0{ }^{\circ} \mathrm{C}$. This was stirred at room temperature for $16 \mathrm{~h}$ resulting in the formation of a precipitate. The solvent was removed in vacuo and the product extracted into toluene $(2 \times 50 \mathrm{~mL})$. Crystals of 1 and $\mathbf{2}$ suitable for X-ray diffraction analysis were grown by slow concentration of toluene solutions at room temperature. In general, for $\mathrm{Ln}=$ $\mathrm{Pr}, \mathrm{Sm}, \mathrm{Gd}, \mathrm{Ho}$ and $\mathrm{Yb}$, the ${ }^{1} \mathrm{H}$ NMR spectra of the complexes were broad due to the paramagnetic and fluxional nature of the compounds, as a result meaningful interpretation was not possible. However, elemental analytical data ( $\mathrm{CHN})$ were obtained on all powders and gave good agreement with theory.

Data for $\operatorname{Pr}\left(\mathrm{O}_{2} \mathbf{N N}^{\prime \prime-\mathrm{Pe}}\right) \mathbf{C l}(\mathbf{T H F})$. Yield $62 \%$. Anal. Found: C 61.30; $\mathrm{H} 9.11 ; \mathrm{N} 3.27 . \mathrm{C}_{42} \mathrm{H}_{70} \mathrm{ClN}_{2} \mathrm{O}_{3}$ Pr: requires C, 60.97; H, 8.53; $\mathrm{N}, 3.39 \%$.

Data for $\operatorname{Sm}\left(\mathbf{O}_{2} \mathbf{N N}^{t-\mathrm{-Pe}}\right) \mathbf{C l}(\mathrm{THF})$. Yield $73 \%$. Anal. Found: C 60.97; H 8.55; N 2.93. $\mathrm{C}_{42} \mathrm{H}_{70} \mathrm{ClN}_{2} \mathrm{O}_{3} \mathrm{Sm}$ : requires $\mathrm{C}, 60.28 ; \mathrm{H}$, $8.43 ; \mathrm{N}, 3.35 \%$.

Data for $\mathbf{G d}\left(\mathrm{O}_{2} \mathbf{N N}^{\prime \prime-\mathrm{Pe}}\right) \mathbf{C l}(\mathbf{T H F})$. Yield $69 \%$. Anal. Found: C $60.11 ; \mathrm{H} 8.52 ; \mathrm{N} 3.12 . \mathrm{C}_{42} \mathrm{H}_{70} \mathrm{ClGdN}_{2} \mathrm{O}_{3}$ : requires C, 59.79; $\mathrm{H}, 8.36$; $\mathrm{N}, 3.32$. X-Ray diffraction data have been previously reported and reveal a dimeric structure. ${ }^{18}$

Data for $\mathrm{Ho}\left(\mathrm{O}_{2} \mathrm{NN}^{t-\mathrm{Pe}}\right) \mathbf{C l}(\mathrm{THF})$. Yield $81 \%$. Anal. Found: C 60.32; $\mathrm{H}$ 8.44; N 3.17. $\mathrm{C}_{42} \mathrm{H}_{70} \mathrm{ClHoN}_{2} \mathrm{O}_{3}$ : requires C, 59.25; H, $8.29 ; \mathrm{N}, 3.29 \%$.

Data for $\mathbf{Y}\left(\mathrm{O}_{2} \mathbf{N N}^{\prime-\text {-Pe }}\right) \mathbf{C l}(\mathbf{T H F})$. Yield $67 \% .{ }^{1} \mathrm{H}$ NMR $\left(\mathrm{C}_{7} \mathrm{D}_{8}\right.$, $500 \mathrm{MHz}, 298 \mathrm{~K}): \delta 7.61\left(\mathrm{~d}, 2 \mathrm{H},{ }^{4} J_{\mathrm{HH}}=1.9 \mathrm{~Hz}, \operatorname{Ar} H\right), 7.43$ $\left({ }^{4} J_{\mathrm{HH}}=1.9 \mathrm{~Hz}, \operatorname{Ar} H\right), 4.02\left(\mathrm{~d},{ }^{4} J_{\mathrm{HH}}=11.9 \mathrm{~Hz}, 2 \mathrm{H}, \operatorname{ArC} H \mathrm{H}\right)$, $3.42\left(\mathrm{br}, \alpha\right.$-THF), $3.13\left(\mathrm{~d},{ }^{2} J_{\mathrm{HH}}=11.9 \mathrm{~Hz}, 2 \mathrm{H}, \operatorname{ArCH} H\right), 2.88$ $\left(\mathrm{d},{ }^{3} J_{\mathrm{HH}}=12.2 \mathrm{~Hz}, 2 \mathrm{H}, \mathrm{NCH}_{2}\right), 2.50\left(\mathrm{~d},{ }^{3} J_{\mathrm{HH}}=12.2 \mathrm{~Hz}, 2 \mathrm{H}\right.$, $\left.\mathrm{NCH}_{2}\right), 2.28\left(\mathrm{~s}, 6 \mathrm{H}, \mathrm{N}\left(\mathrm{CH}_{3}\right)_{2}\right), 2.08\left(\mathrm{~m}, 8 \mathrm{H}, \mathrm{CH}_{2} \mathrm{CH}_{3}\right), 1.49$ (br, $\beta$-THF), 1.22 (m, 36H, $\mathrm{CH}_{3}$ ). Anal. Found: $\mathrm{C} 66.12 ; \mathrm{H} 9.57$; N 3.55. $\mathrm{C}_{42} \mathrm{H}_{70} \mathrm{ClN}_{2} \mathrm{O}_{3} \mathrm{Y}: \mathrm{C}, 65.06 ; \mathrm{H}, 9.10 ; \mathrm{N}, 3.61 \%$.
Data for $\mathbf{Y b}\left(\mathbf{O}_{2} \mathbf{N N}^{\prime \prime-\mathrm{Pe}}\right) \mathbf{C l}(\mathbf{T H F})$. Yield $70 \%$. Anal. Found: C 58.93; $\mathrm{H}$ 8.30; N 3.11. $\mathrm{C}_{42} \mathrm{H}_{70} \mathrm{ClN}_{2} \mathrm{O}_{3} \mathrm{Yb}$ : requires $\mathrm{C}, 58.69 ; \mathrm{H}$, $8.21 ; \mathrm{N}, 3.26 \%$.

Data for $\mathbf{Y}\left(\mathbf{O}_{2} \mathbf{N N}^{\prime t-\mathrm{Bu}}\right) \mathbf{C l}(\mathbf{T H F}), 1$. Yield $65 \% .{ }^{1} \mathrm{H} \mathrm{NMR}\left(\mathrm{C}_{7} \mathrm{D}_{8}\right.$, $270 \mathrm{MHz}, 333 \mathrm{~K}): \delta 7.52\left(\mathrm{~d}, 2 \mathrm{H},{ }^{4} J_{\mathrm{HH}}=2.3 \mathrm{~Hz}, \operatorname{Ar} H\right), 7.41(\mathrm{~d}, 2 \mathrm{H}$, $\left.{ }^{4} J_{\mathrm{HH}}=2.4 \mathrm{~Hz}, \operatorname{Ar} H\right), 4.11\left(\mathrm{~d}, 2 \mathrm{H},{ }^{2} J_{\mathrm{HH}}=11.2 \mathrm{~Hz}, \operatorname{ArCHH}\right), 3.78$ (br, 4H, $\left.\alpha-\mathrm{CH}_{2}, \mathrm{THF}\right), 2.88\left(\mathrm{~d}, 2 \mathrm{H},{ }^{2} J_{\mathrm{HH}}=11.2 \mathrm{~Hz}, \mathrm{ArCH} H\right.$ ), 2.36 (br, $\left.2 \mathrm{H}, \mathrm{CH}_{2}\right), 2.12$ (br, $\left.2 \mathrm{H}, \mathrm{CH}_{2}\right), 1.90$ (br, $\left.6 \mathrm{H}, \mathrm{N}\left(\mathrm{CH}_{3}\right)_{2}\right)$, $1.73\left(\mathrm{~s}, 18 \mathrm{H}, \mathrm{C}\left(\mathrm{CH}_{3}\right)_{3}\right), 1.54\left(\mathrm{br}, 4 \mathrm{H}, \beta-\mathrm{CH}_{2}, \mathrm{THF}\right), 1.44(\mathrm{~s}, 18 \mathrm{H}$, $\left.\mathrm{C}\left(\mathrm{CH}_{3}\right)_{3}\right) \cdot{ }^{13} \mathrm{C}\left\{{ }^{1} \mathrm{H}\right\}$ NMR $\left(\mathrm{C}_{7} \mathrm{D}_{8}, 67.5 \mathrm{MHz}, 333 \mathrm{~K}\right): \delta 161.5(\mathrm{C}-$ O), $143.1(\mathrm{C}), 136.2(\mathrm{C}), 126.6(\mathrm{C}), 122.6(\mathrm{CH})$, one $\mathrm{CH}$ masked by deutero-solvent, $71.4\left(\alpha-\mathrm{CH}_{2}, \mathrm{THF}\right), 65.3\left(\mathrm{CH}_{2}\right), 59.4\left(\mathrm{CH}_{2}\right)$,

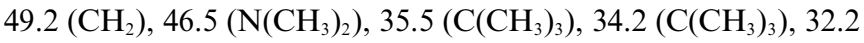

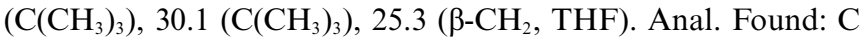
63.53; H 8.27; N 4.13. $\mathrm{C}_{38} \mathrm{H}_{62} \mathrm{ClN}_{2} \mathrm{O}_{3} \mathrm{Y}$ : requires $\mathrm{C}, 63.45 ; \mathrm{H}, 8.69$; $\mathrm{Cl}, 4.93 ; \mathrm{N}, 3.89 \%$. X-Ray diffraction data: vide supra.

Data for $\mathrm{Sm}\left(\mathrm{O}_{2} \mathrm{NN}^{\prime \prime-\mathrm{Bu}}\right) \mathrm{Cl}(\mathrm{THF}), \mathrm{THF}$ analogue of 2 . Yield $70 \%$. Anal. Found: C 57.89; $\mathrm{H}$ 7.89; $\mathrm{N}$ 3.33. $\mathrm{C}_{38} \mathrm{H}_{62} \mathrm{ClN}_{2} \mathrm{O}_{3} \mathrm{Sm}$ : requires $\mathrm{C}, 58.46 ; \mathrm{H}, 8.00 ; \mathrm{N}, 3.59 \%$. X-Ray diffraction data: vide supra.

\section{General polymerization procedure}

Polymerizations were conducted in stirred vials in a glove box. To toluene solutions $(2 \mathrm{~mL})$ of initiator $(0.0118 \mathrm{mmol}), \varepsilon$-CL $(131 \mu \mathrm{L}, 1.18 \mathrm{mmol})$ was added. These were stirred at room temperature for $24 \mathrm{~h}$. The vials were removed from the glove box and $0.5 \mathrm{~mL}$ from each was added to pentane $(1 \mathrm{~mL})$. The solvent was removed in vacuo and the resulting samples were subjected to GPC analysis. Conversions of monomer to polymer were determined using ${ }^{1} \mathrm{H}$ NMR spectroscopy. Due to the presence in some cases of paramagnetic contaminants, the polymers were further purified by repeated toluene dissolution and methanol precipitation cycles.

\section{Conclusions}

We have shown that lanthanide amine-bis-phenolate complexes, $\mathrm{Ln}\left(\mathrm{O}_{2} \mathrm{NN}^{\prime \mathrm{R}}\right) \mathrm{Cl}(\mathrm{THF})$, can be formed in moderate yields via the reaction of the corresponding lithium complex with $\mathrm{LnCl}_{3} \cdot \mathrm{THF}_{x}$ in THF. Somewhat surprisingly, we see no evidence for 'ate' complex formation and solid state structures reveal monomeric species. In attempts to isolate $\varepsilon$-CL adducts of these species, it was revealed that over a prolonged reaction time, polymerization was initiated and that these complexes yield low molecular weight polyesters. The polymer products show no end-groups in their ${ }^{1} \mathrm{H}$ NMR spectra indicating that cyclic polymers might have formed. The similarity of $M_{\mathrm{n}}$ for all the polymers produced by these catalysts may be a result of steric constraint enforced by the chelate rings within the initiator's structure. These rings enforce a specific chain length when polymer 'back-biting' will be forced to occur and yield the cyclic polymer. Therefore, the metal-phenoxide or the metal-amine bonds in amine bis(phenolate) Ln complexes, although not as reactive as metal-amido or metal-alkoxide bonds, can facilitate the ROP of $\varepsilon$-CL. This reactivity should be noted when studying related initiator systems, as by-products may be produced and molecular weight distributions increased via the mechanisms at play here. We also note that dimeric Ln-phenolate 
chloride complexes behave differently in this reaction compared with monomeric species.

\section{Acknowledgements}

F. M. K. thanks the Royal Society (University Research Fellowship), the EPSRC (Studentship, C. E. W.), NSERC (Discovery Grant and RTI) and Canada Foundation for Innovation (Leaders Opportunity Grant). A. A. T. thanks the Russian Foundation for Basic Research (Grants 08-03-00391, 06-03-32728-a and 07-0312164-ofi), Presidium of the Russian Academy of Science (RAS), and RAS Chemistry and Material Science Division.

\section{Notes and references}

1 (a) A. Hamitou, T. Ouhadi, R. Jerome and P. H. Teyssié, J. Polym. Sci., 1977, 15, 865; (b) M. Endo, T. Aida and S. Inoue, Macromolecules, 1987, 20, 2982; (c) R. C. Yu, C. H. Hung, J. H. Huang, H. Y. Lee and J. T. Chen, Inorg. Chem., 2002, 41, 6450; (d) D. Chakraborty and E. Y. X. Chen, Organometallics, 2003, 22, 769; (e) C. T. Chen, C. A. Huang and B. H. Huang, Macromolecules, 2004, 37, 7968; $(f)$ P. Hormnirun, E. L. Marshall, V. C. Gibson, J. P. White and D. J. Williams, J. Am. Chem. Soc., 2004, 126, 2688; $(g)$ N. Nomura, T. Aoyama, R. Ishii and T. Kondo, Macromolecules, 2005, 38, 5363.

2 (a) J. Okuda and I. L. Rushkin, Macromolecules, 1993, 26, 5530; (b) Y. Takashima, Y. Nakayama, K. Watanabe, T. Itono, N. Ueyama, A. Nakamura, H. Yasuda and A. Harada, Macromolecules, 2002, 35, 7538.

3 (a) H. Yavuz, C. Babaç, K. Tuzlakoğlu and E. Pişkin, Polym. Degrad. Stab., 2002, 75, 431; (b) A. Kowalski, J. Libiszowski, T. Biela, M. Cypryk, A. Duda and S. Penczek, Macromolecules, 2005, 38, 8170.

4 (a) M. Vivas and J. Contreras, Eur. Polym. J., 2003, 39, 43; (b) H. Y. Chen, B. H. Huang and C. C. Lin, Macromolecules, 2005, 38, 5400.

5 E. L. Marshall, V. C. Gibson and H. S. Rzepa, J. Am. Chem. Soc., 2005, 127, 6048.

6 S. J. McLain and N. E. Drysdale, Chem. Abstr., 1992, 203, 160-poly; S. J. McLain and N. E. Drysdale, Polym. Prepr. (Am. Chem. Soc., Div. Polym. Chem.), 1992, 33, 174.

7 Y. Shen, Z. Shen, Y. Zhang and K. Yao, Macromolecules, 1996, 29, 8289.

8 P. W. Roesky, M. T. Gamer, M. Puchner and A. Greiner, Chem.-Eur. J., $2002,8,5265$.

9 A. Lara-Sanchez, A. Rodriguez, D. L. Hughes, M. Schormann and M. Bochmann, J. Organomet. Chem., 2002, 663, 63.

10 S. C. F. Kui, H. W. Li and H. K. Lee, Inorg. Chem., 2003, 42, 2824.

11 J. Cheng, D. Cui, W. Chen, N. Hu, T. Tang and B. Huang, J. Organomet. Chem., 2004, 689, 2646.

12 (a) Y. Yao, M. Ma, X. Xu, Y. Zhang, Q. Shen and W. T. Wong, Organometallics, 2005, 24, 4014; (b) Y. Yao, X. Xu, B. Liu, Y. Zhang, Q. Shen and W. T. Wong, Inorg. Chem., 2005, 44, 513; (c) X. Xu, Z. Zhang, Y. Yao, Y. Zhang and Q. Shen, Inorg. Chem., 2007, 46, 9379.

13 C. Jing-Lei, Y. Ying-Ming, L. Yun-Jie, Z. Li-Ying, Z. Yong and S. Qi, J. Organomet. Chem., 2004, 689, 1019.

14 (a) Y. Luo, Y. Yao, Q. Shen, K. Yu and L. Weng, Eur. J. Inorg. Chem., 2003, 318; (b) Y. Yao, Y. Luo, J. Chen, Z. Zhang, Y. Zhang and Q. Shen, J. Organomet. Chem., 2003, 679, 229.

15 (a) A. Amgoune, C. M. Thomas and J.-F. Carpentier, Macromol. Rapid Commun., 2007, 28, 693; (b) F. Bonnet, A. R. Cowley and P. Mountford, Inorg. Chem., 2005, 44, 9046; (c) A. Amgoune, C. M. Thomas, T. Roisnel and J.-F. Carpentier, Chem.-Eur. J., 2006, 12, 169; (d) X. Liu, X. Shang,
T. Tang, N. Hu, F. Pei, D. Cui, X. Chen and X. Jing, Organometallics, 2007, 26, 2747; (e) H. E. Dyer, S. Huijser, A. D. Schwarz, C. Wang, R. Duchateau and P. Mountford, Dalton Trans., 2008, 32; $(f)$ Y. Yao, M. Ma, X. Xu, Y. Zhang, Q. Shen and W.-T. Wong, Organometallics, $2005,24,4014$.

16 F. Bonnet, A. C. Hillier, A. Collins, S. R. Dubberley and P. Mountford, Dalton Trans., 2005, 421.

17 S. Agarwal and M. Puchner, Eur. Polym. J., 2002, 38, 2365.

18 F. M. Kerton, A. C. Whitwood and C. E. Willans, Dalton Trans., 2004, 2237.

19 Y. Matsuo, K. Mashima and K. Tani, Organometallics, 2001, 20, 3510.

20 E. Martin, P. Dubois and R. Jérôme, Macromolecules, 2003, 36, 5934.

21 M. Visseaux, C. H. Brachais, C. Boisson and K. Tortosa, C. R. Acad. Sci., Ser. IIc: Chim., 2000, 631.

22 F. M. Kerton, C. M. Kozak, K. Lüttgen, C. E. Willans, R. J. Webster and A. C. Whitwood, Inorg. Chim. Acta, 2006, 359, 2819.

23 (a) G. W. Rabe, M. Zhang-Presse, F. A. Rieder and G. P. A. Yap, Inorg. Chem., 2003, 42, 3527; (b) H. Ma, T. P. Spaniol and J. Okuda, Dalton Trans., 2003, 4770; (c) C. L. Boyd, T. Toupance, B. R. Tyrell, B. D. Ward, C. R. Wilson, A. R. Cowley and P. Mountford, Organometallics, 2005, 24, 309; (d) D. J. H. Emslie, W. E. Piers, M. Parvez and R. McDonald, Organometallics, 2002, 21, 4226; (e) P. N. O'Shaughnessy, P. D. Knight, C. Morton, K. M. Gillespie and P. Scott, Chem. Commun., 2003, 1770; (f) M. W. Essig, D. W. Keogh, B. L. Scott and J. G. Watkin, Polyhedron, 2001, 20, 373; (g) P. C. Leverd, D. Rinaldo and M. Nierlich, Eur. J. Inorg. Chem., 2001, 2021.

24 M. G. Davidson, C. T. O'Hara, M. D. Jones, C. G. Keir, M. F. Mahon and G. Kociok-Köhn, Inorg. Chem., 2007, 46, 7686.

25 M. Save, M. Schappacher and A. Soum, Macromol. Chem. Phys., 2002, 203, 889 .

26 D. A. Culkin, W. Jeong, S. Csihony, E. D. Gomez, N. P. Balsara, J. L. Hedrick and R. M. Waymouth, Angew. Chem., Int. Ed., 2007, 46, 2627.

27 W. J. Evans, J. L. Shreeve, J. W. Ziller and R. J. Doedens, Inorg. Chem., 1995, 34, 576.

28 F. Peng and Z. Shen, J. Appl. Polym. Sci., 2007, 106, 1828.

29 (a) A. J. Nijenhuis, D. W. Grijpma and A. J. Pennings, Macromolecules, 1992, 25, 6419; (b) G. Schwach, J. Coudane, R. Engel and M. Vert, J. Polym. Sci., Part A: Polym. Chem., 1997, 35, 3431; (c) P. J. A. In,'t Veld, E. M. Vekner, P. Van De Witte, J. Hamhuis, P. J. Dijkstra and J. Feijen, J. Polym. Sci., Part A: Polym. Chem., 1997, 35, 219; (d) C.-M. Dong, K.-Y Qiu, Z.-W. Gu and X.-D. Feng, Macromolecules, 2001, 34, 4691; (e) R. Hoogenboom, B. C. Moore and U. S. Schubert, Chem. Commun., 2006, 4010; (f) N. Xu, F.-Z Lu, F.-S Du and Z.-C. Li, Macromol. Chem. Phys., 2007, 208, 730.

30 K. C. Hultzch, T. P. Spaniol and J. Okuda, Organometallics, 1997, 16, 4845.

31 (a) C.-A. Huang and C.-T. Chen, Dalton Trans., 2007, 5561; (b) Y. Sarazin, R. H. Howard, D. L. Hughes, S. M. Humphrey and M. Bochmann, Dalton Trans., 2006, 340; (c) H. Zhou, H. Guo, Y. Yao, L. Zhou, H. Sun, H. Sheng, Y. Zhang and Q. Shen, Inorg. Chem., 2007, 46, 958.

32 W. E. Piers, P. J. Shapiro, E. E. Bunel and J. E. Bercaw, Synlett, 1990, 74.

33 (a) E. Y. Tshuva, I. Goldberg and M. Kol, Organometallics, 2001, 20, 3017; (b) F. M. Kerton, S. Holloway, A. Power, R. G. Soper, K. Sheridan, J. M. Lynam, A. C. Whitwood and C. E. Willans, Can. J. Chem., 2008, 86, 435 .

34 G. M. Sheldrick, SHELXTL v. 6.12, Structure Determination Software Suite, Bruker AXS, Madison, Wisconsin, USA, 2000.

35 G. M. Sheldrick, SADABS v.2.01, Bruker/Siemens Area Detector Absorption Correction Program, Bruker AXS, Madison, Wisconsin, USA, 1998. 